\title{
Effect of Replacing Groundnut Cake with Dried Distillers' Grains with Solubles (DDGS) on Nutrient Utilization Efficiency of Magra Lambs
}

\author{
Umesh Kumar Prajapat $^{1 *}$, T. Sharma ${ }^{2}$ Nirmala Saini $^{3}$ and Bhupendra Kaswan ${ }^{2}$ \\ ${ }^{1}$ Livestock Feed Resource Management E Technology Centre, Rajasthan University of Veterinary and Animal Sciences, \\ Bikaner, Rajasthan, INDIA \\ ${ }^{2}$ Department of Animal Nutrition, College of Veterinary and Animal Science (RAJUVAS), Bikaner, Rajasthan, INDIA \\ ${ }^{3} A R C$-Central Sheep and Wool Research Institute, Bikaner, Rajasthan, INDIA \\ "Corresponding author: UK Prajapat; E-mail: umeshkumarprajapat@gmail.com
}

Received: 19 July, 2021

Revised: 09 Aug., 2021

Accepted: 12 Aug., 2021

\begin{abstract}
Non conventional feed resources are gaining importance in livestock feeding for reducing gap between demand and supply of feeds. DDGS is an agro industrial by product and it is obtained during ethanol production. It is most economic protein feed (crude protein $43.11 \%$ ) for livestock feeding and it can be used as replacement of traditional protein feeds like groundnut meal and soybean meal. In current study, a feeding trial followed by metabolism trial of seven days was conducted on twenty 3-4 months old male Magra lambs at the sheep farm of ARC-CSWRI, Bikaner under "Network Project on Sheep Improvement of Magra Sheep" during period of May to July of year 2019 following randomized block design while dividing them into four groups of 5 lambs in each $\left(\mathrm{T}_{1}-\mathrm{T}_{4}\right)$. In metabolism trial animals were harnessed with faecal bags and urine collection devices and samples of feed stuffs and their residues were collected individually for all the animals for chemical analysis. The faecal and urine samples for 24 hours were collected for analysis. The results revealed significant $(\mathrm{P}<0.05)$ effect of incorporation of DDGS on dry matter and crude protein digestibility, whereas the digestibility of OM, EE, CF, NFE, NDF, ADF and HC found to be non-significant among various treatment groups.
\end{abstract}

\section{HIGHLIGHTS}

0 Dry matter and crude protein digestibility was significantly higher in DDGS incorporated groups.

( Dried distillers grains with solubles i.e. DDGS can be incorporated in lamb ration up to level of $15 \%$.

Keywords: DDGS, Magra, nutrient utilization efficiency, Non conventional feed resources

In India, about $70 \%$ of the village farmers depend upon agriculture for their main source of income. The total contribution of agriculture and allied sectors (including agriculture, livestock, forestry and fishery sub sectors) in terms of percentage of GDP was $15.87 \%$ during 2018-19 (Anonymous, 2019). Sheep plays an important role in rural economy of arid and semi arid zone of Rajasthan through gainful employment to large number of illiterate and socially backward farmers (Agrawal et al., 2018). Sheep rearing act as a pillar for rural economy by providing wool, meat and manure i.e. three different sources of income to the farmers (Sarita et al., 2018). High pricing of conventional feed sources such as groundnut cake is compelling farmers for utilization of non-conventional feed resources so as to make farming lucrative. Incorporation of non-conventional feed resources such as DDGS in ration of livestock has also appeared as an option in arid and semi arid region of Rajasthan. The utilization of non-conventional feedstuffs not only helps in shrinking the gap between demand and supply of feed resources but also make ration economic. In India, there is

How to cite this article: Prajapat, U.K., Sharma, T., Saini, N. and Kaswan, B. (2021). Effect of Replacing Groundnut Cake with Dried Distillers Grains with Solubles (DDGS) on Nutrient Utilization Efficiency of Magra Lambs. J. Anim. Res., 11(05): 853-856.

Source of Support: None; Conflict of Interest: None 6 
a deficit of $23.40 \%, 11.24 \%$ and $28.90 \%$ in the availability of dry fodder, green fodder and concentrates, respectively (Roy et al., 2019). DDGS is an agro industrial byproduct and it is obtained in fermentation process of cereal grains during ethanol production (Belyea et al., 2004). DDGS is a most economic protein feed for livestock feeding and it can be used as replacement of traditional protein feeds like groundnut meal and soybean meal. DDGS is characterized with relatively higher nutrient digestibility (Lemenager et al., 2006; Todorov et al., 2007) including the crude fiber. Higher protein digestibility was reported by Leupp et al. (2009). Etman et al. (2014) observed improved digestibility of all nutrients in lambs. The objective of present study was to determine the effect of replacing groundnut cake with dried distillers' grains with solubles (DDGS) on nutrient utilization efficiency of Magra lambs in arid zone of Rajasthan.

\section{MATERIALS AND METHODS}

A feeding trial followed by metabolism trial of seven days was conducted on twenty 3-4 months old male Magra lambs at the sheep farm of ARC-CSWRI, Bikaner under "Network Project on Sheep Improvement of Magra Sheep" during period of May to July of year 2019. Animals were housed in well ventilated, hygienic and protected sheds. The experimental lambs were distributed in complete randomized block design into four groups having five lambs in each group. The ingredients used in four combinations of total mixed rations were groundnut cake with DDGS at different levels and were used for $a d$ $l i b$ feeding of experimental lambs. Four isonitrogenous and isocaloric total mixed rations were prepared by using groundnut straw, ground nut cake, wheat bran, molasses, urea, mineral mixture, and salt with levels of DDGS to be $0,5,10$ and 15 per cent while maintaining roughage to concentrate ratio of 60:40 and processed at feed processing plant of ARC-CSWRI, Bikaner. The percent ingredient compositions of experimental total mixed rations have been shown in Table 1.

The metabolism trial was conducted to assess nutrients digestibility and in trial animals were harnessed with faecal bags and urine collection devices. During metabolic trial samples of feed stuffs and their residues were collected individually for all the animals for chemical analysis to arrive at exact intake of nutrients. Pre weighed plastic buckets were used for collection of faeces from each animal.

Table 1: Experimental total mixed ration for various treatments (\% part ingredient composition)

\begin{tabular}{lllll}
\hline Ingredient & $\mathbf{T}_{\mathbf{1}}$ (Control) & $\mathbf{T}_{\mathbf{2}}$ & $\mathbf{T}_{\mathbf{3}}$ & $\mathbf{T}_{\mathbf{4}}$ \\
\hline Groundnut straw & 60 & 60 & 60 & 60 \\
GNC & 15 & 10 & 5 & 0 \\
DDGS & 0 & 5 & 10 & 15 \\
Molasses & 10 & 10 & 10 & 10 \\
Wheat bran & 12 & 12 & 12 & 12 \\
Urea & 1 & 1 & 1 & 1 \\
Mineral mixture & 1 & 1 & 1 & 1 \\
Salt & 1 & 1 & 1 & 1 \\
\hline
\end{tabular}

Urine was also collected separately for each animal by urine collection bags. Collection of faeces as well as urine was done daily at 7:00 A.M. Faeces were weighed and urine was measured using a measuring cylinder. During the period of collection, faeces and urine samples of each animal were taken after thorough mixing. For determination of dry matter (DM), proximate principles and fibre fractions, 1/100 sample of faeces was dried at $100^{\circ} \mathrm{C}$ in the oven and pooled for 7 days for individual animals. The pooled samples were ground and analyzed. Similarly, the 1/500 sample of total urine of individual animals was taken separately in marked Kjeldahl's flasks containing concentrate $\mathrm{H}_{2} \mathrm{SO}_{4}$ daily and pooled for 7 days.

Samples of feed offered and their residues left, faeces and urine were analyzed for proximate constituents as per AOAC (2005). The protein content of feed, faeces and urine were determined following standard Kjeldahl's method using Kelplus Automatic Nitrogen Analyzer (Pelican Equip.). Determination of ether extract in feed and faeces was done with the help of Soxhlet's apparatus. For dry matter, crude fibre and total ash determination, standard conventional procedures were followed. The conventional Weende's method was followed for calculation of nitrogen free extract. The method of Goering and Van Soest (1970) was adopted to evaluate the cell wall constituents. The data obtained in the experiment were analyzed statistically for effect of treatment in complete randomized block design as per Snedecor and Cochran (2004) and significance of mean differences was tested by Duncan's New Multiple Range Test (DNMRT) as modified by Kramer (1956). 


\section{RESULTS AND DISCUSSION}

Other than the physiological parameters, qualitative and quantitative properties of feed, digestibility of nutrients present in feed are viewed as significant attribute to evaluate the nutritional worth of feed. The chemical composition of experimental total mixed ration has been presented in Table 2.

Table 2: Chemical composition of total mixed rations offered to various experimental groups (\% DM basis)

\begin{tabular}{llllll}
\hline \multirow{2}{*}{ Sl. No. } & Chemical & \multicolumn{4}{c}{ Total mixed rations } \\
\cline { 2 - 6 } & Composition & $\mathbf{T}_{1}$ & $\mathbf{T}_{2}$ & $\mathbf{T}_{3}$ & $\mathbf{T}_{4}$ \\
\hline 1 & Dry matter & 88.32 & 88.03 & 89.45 & 89.25 \\
2 & Organic matter & 87.27 & 86.75 & 86.35 & 85.99 \\
3 & Crude protein & 16.93 & 16.94 & 16.96 & 16.97 \\
4 & Ether extract & 2.88 & 2.92 & 2.91 & 2.93 \\
5 & Crude fibre & 21.91 & 21.89 & 22.11 & 21.99 \\
6 & Total ash & 12.73 & 13.25 & 13.65 & 14.01 \\
7 & NFE & 45.55 & 45.00 & 44.37 & 44.10 \\
8 & NDF & 46.78 & 47.04 & 46.98 & 47.10 \\
9 & ADF & 30.52 & 31.65 & 30.98 & 31.90 \\
10 & Hemicellulose & 16.26 & 15.39 & 16.00 & 15.20 \\
\hline
\end{tabular}

The daily feed intake and faeces voided by the experimental lambs of different treatments were recorded during the metabolism trial of seven days. All the samples were subjected for analysis of proximate principles as well as various fibre fractions in all the treatment groups and the data obtained were compiled for calculation of digestibility coefficients of dry matter (DM), organic matter (OM), crude protein $(\mathrm{CP})$, ether extract $(\mathrm{EE})$, crude fibre $(\mathrm{CF})$, nitrogen free extract (NFE), neutral detergent fibre (NDF), acid detergent fibre (ADF) and hemicelluloses (HC) for assessment of nutrient availability from experimental total mixed ration and the mean values of their digestibility coefficients for various treatment groups have been presented in Table 3.

The results revealed significant $(\mathrm{P}<0.05)$ effect of incorporation of DDGS in total mixed ration of lambs on dry matter digestibility and the highest dry matter digestibility was observed in $\mathrm{T}_{4}$ group, which was though comparable with $\mathrm{T}_{2}$ and $\mathrm{T}_{3}$ treatment groups in statistical terms. Lowest value has been found in $T_{1}$ i.e. control group, but it was comparable with $\mathrm{T}_{2}$ treatment group in statistical terms. The crude protein digestibility was also significantly higher $(\mathrm{P}<0.05)$ in $\mathrm{T}_{4}$ group, which was significantly higher than rest of the treatment groups, though the crude protein digestibility of $T_{1}, T_{2}$ and $T_{3}$ treatment groups was comparable with each others in statistical terms. Lowest value was recorded in $\mathrm{T}_{1}$ i.e. control group. The digestibility of OM, EE, CF, NFE, $\mathrm{NDF}, \mathrm{ADF}$ and $\mathrm{HC}$ found to be non-significant among various treatment groups.

In the study the findings of dry matter and crude protein digestibility fall in line with the findings of Etman et al. (2014); also reported significant effect of DDGS on dry matter and crude protein digestibility in lambs fed ration containing DDGS upto 40\%. Felix et al. (2012) reported significantly improved dry matter digestibility. In present study digestibility of other nutrients i.e. organic matter, ether extract, crude fiber, nitrogen free extract observed to be non-significant among various treatment groups, do not fall in line with the findings of Etman et al. (2014); reported significant effect of DDGS on organic matter, ether extract, crude fiber, nitrogen free extract digestibility in lambs fed with ration containing DDGS upto $40 \%$. The findings of digestibility of nutrients i.e. organic matter, ether extract, crude fiber, nitrogen free extract, NDF, ADF,

Table 3: Average digestibility coefficients of DM, gross nutrients and fibre fractions in various treatment groups

\begin{tabular}{llllllllll}
\hline $\begin{array}{l}\text { Treatment } \\
\text { groups }\end{array}$ & $\mathbf{9 M}$ & $\mathbf{O M}$ & $\mathbf{C P}$ & $\mathbf{E E}$ & $\mathbf{C F}$ & $\mathbf{N F E}$ & NDF & ADF & HC \\
\hline$n_{\mathrm{T}}$ & $60.35^{\mathrm{a}}$ & 62.36 & $70.35^{\mathrm{a}}$ & 63.40 & 55.14 & 62.27 & 54.08 & 44.34 & 72.38 \\
$\mathrm{~T}_{2}$ & $61.51^{\mathrm{ab}}$ & 63.27 & $71.42^{\mathrm{a}}$ & 64.08 & 56.49 & 62.88 & 55.54 & 45.52 & 76.14 \\
$\mathrm{~T}_{3}$ & $62.09^{\mathrm{b}}$ & 63.64 & $71.56^{\mathrm{a}}$ & 66.13 & 56.19 & 62.93 & 55.60 & 44.68 & 78.31 \\
$\mathrm{~T}_{4}$ & $62.60^{\mathrm{b}}$ & 63.95 & $73.38^{\mathrm{b}}$ & 67.12 & 56.94 & 62.64 & 56.41 & 46.91 & 77.35 \\
\hline SEM & $\mathbf{0 . 5 1 4}$ & $\mathbf{0 . 4 7 3}$ & $\mathbf{0 . 5 6 7}$ & $\mathbf{1 . 1 3 6}$ & $\mathbf{0 . 7 4 1}$ & $\mathbf{0 . 5 1 0}$ & $\mathbf{0 . 6 2 0}$ & $\mathbf{1 . 2 7 2}$ & $\mathbf{1 . 8 2 8}$ \\
\hline
\end{tabular}

Note: Means with different superscripts in a column differ significantly $(\mathrm{P}<0.05)$. 
cellulose and hemicelluloses remained non-significant is comparable with the results of study of Rao (2016) reported no significant effect of DDGS in lambs on digestibility of nutrients. The results of present study for crude fiber and fiber fractions i.e. NDF and ADF digestibility are in agreement with the observations of Felix et al. (2012). The improvement in the digestibility coefficients of all the nutrient of DDGS incorporated rations might be attributed to higher availability of the nutrient contents of DDGS as reported by Leupp et al. (2009), May et al. (2010), Schauer et al. (2006) and Etman et al. (2014).

\section{CONCLUSION}

In study, the dry matter and crude protein digestibility was significantly higher in DDGS incorporated groups and digestibility of other gross nutrients and fibre fractions did not vary significantly but remained numerically higher in DDGS incorporated groups than control group. Therefore, it can be concluded from present study that dried distillers grains with solubles i.e. DDGS can be incorporated in lamb ration up to level of $15 \%$ for improvement in nutrient utilization in lambs for improvement in the overall performance of the lambs. Though, further study with large population size and higher levels of DDGS incorporation may address the effect more precisely.

\section{ACKNOWLEDGEMENTS}

We gratefully acknowledge the help offered by Head, Department of Animal Nutrition, College of Veterinary and Animal Science, Bikaner; Dean, College of Veterinary and Animal Science, Bikaner and Head, ARC-CSWRI, Bikaner for providing facilities to conduct the experiment.

\section{REFERENCES}

Agrawal, V.K., Gehlot, G.C., Asraf, M., Dhakad, G., Thakur, S. and Gupta, S.R. 2018. Study on genetic polymorphism of myostatin gene in Magra sheep. Vet. Pract., 19(1): 9-11.

Anonymous 2019. Ministry of Statistics and Programme implementation (2018-19), Planning Commission, Government of India.

Belyea, R., Rausch, K.D. and Tumbleson, M.E. 2004. Composition of corn and distillers dried grains with solubles from dry grind ethanol processing. Biores. Technol., 94(3): 293-298.
Etman, K.E.I., El-Monayer, T.I., Sayed, S.K., El-Sayed, F.A. and Mona, E. Farag 2014. Effect of feeding different levels of DDGS as a source of energy on sheep performance. J. Anim. Poult. Produc., 5(2): 27-41.

Felix, T.L., Zerby, H.N., Moeller, S.J. and Loerch, S.C. 2012. Effects of increasing dried distillers grains with soluble on performance, carcass characteristics and digestibility of feedlot lambs. J. Anim. Sci., 90(4): 1356-1363.

Goering, H.K. and Van Soest, P.J. 1970. Forage Fibre Analysis, ARS, USDA. Agricultural Handbook No. 379, SDA, Washington, DC. pp. 1-12.

Kramer, C.Y. 1956. Extension of multiple range tests to group means with unequal numbers of replications. Biometrics, 12(3): 307-310.

Lemenager, R., Applegate, T., Claeys, MDonkin, S., Jonson, T., Lake, S., Neary, M., Radcliffe, S., Richert, B., Schinckel, A., Schutz, M. and Sutton, A. 2006. Bioenergy: The value of distillers' grains as a livestock feed. Purdue University. http:// www.ces.purdue.edu/new.

Leupp, J.L., Lardy, G.P., Karges, K.K. and Caton, J.S. 2009. Effects of increasing level of corn distillers dried grains with solubles on intake, digestion, and ruminal fermentation in steers fed seventy percent concentrate diets. J Anim. Sci., 87(9): 2906-2912.

May, M.L., Quinn, M.J., Depenbusch, B.E., Reinhard, C.D., Gibson, L., Karges, K.K., Cole, N.A. and Drouillard, J.S. 2010. Dried distillers grains with solubles reduced corn silage level in beef finishing diet. J Anim. Sci., 88(7): 2456-2463.

Rao, D.C. 2016. Effect of dietary incorporation of dried distillers grains with solubles (DDGS) on performance in growing native ram lambs. M.V.Sc. thesis. Sri P.V. Narasimha Rao Telangana state University for Veterinary, Animal and Fishery Sciences, Rajendranagar, Hyderabad.

Roy, A.K., Agrawal, R.K., Bhardwaj, N.R., Mishra, A.K. and Mahanta, S.K. 2019. Revisiting national forage demand and availability. In: Indian Fodder Scenario: Redefining state wise status (eds. A.K. Roy, R.K. Agrawal, N.R. Bhardwaj). ICAR- AICRP on Forage Crops and Utilization, Jhansi, India, pp. 1-21.

Sarita, Mathur, M., Dadhich, H., Dhaka, V.K., Kumar, A., Dagar, K. C., Dadhich, A. and Agarwal, M. 2018. Occurrence and pathology of pyelonephritis in Sheep (Ovis aries). Vet. Pract., 19(1): 40-41.

Schauer, C.S., Berg, P.B., Stamm, M., Stecher, D.M., Pearson, D. and Drolc, D. 2006. Influence of dried distillers' grains of feed lot performance and carcass characteristics of finishing feedlot. Western Dakota sheep Beef Day, 47: 34-37.

Snedecor, G.W. and Cochran, W.G. 2004. Statistical methods. $8^{\text {th }}$ Edn., East West Press Pvt. Ltd., New Delhi.

Todorov, N., Krachunov, I., Djuvinov, D. and Alexandrov, A. 2007. Handbook of Animal Nutrition. Matkom, Sofia (Bg). 